\title{
IAMJ
}

INTERNATIONAL AYURVEDIC MEDICAL JOURNAL

\section{A CASE STUDY ON AYURVEDIC MANAGEMENT OF VRIKKASHMARI}

\author{
Neha Grover ${ }^{1}$, Pramod Kumar Mishra ${ }^{2}$, Indu Sharma ${ }^{3}$, Divya Singh Charan ${ }^{4}$ \\ ${ }^{1}$ MD Scholar P.G. Department of Kayachikitsa, \\ ${ }^{2}$ Professor and HOD, P.G. Department of \\ Kayachikitsa, University College of Ayurveda, Dr. Sarvepalli Radhakrishnan Rajasthan \\ Ayurved University Jodhpur, Rajasthan, India. \\ ${ }^{3}$ Associate Professor P.G. Department of Kayachikitsa, Govt. Ayurvedic College of Udaipur, Rajasthan, India. \\ ${ }^{4}$ MD Scholar P.G. Department of Kayachikitsa,
}

Corresponding Author: n.grover17@gmail.com

\section{https://doi.org/10.46607/iamj5009102021}

(Published Online: October 2021)

Open Access

(C) International Ayurvedic Medical Journal, India 2021

Article Received: 17/09//2021 - Peer Reviewed: 05/10/2021 - Accepted for Publication: 06/10/2021

\section{Check for updates}

\section{ABSTRACT}

Since ancient times Ashmari is mentioned in Ayurvedic texts. Ashmari is a disease related to the urinary system (Mutravahasrotas). Mutrashmari is described under Asthamahagad (difficult to cure) in Ayurveda. It possesses symptoms such as Jwara (Fever), Basti Pida (Discomfort and pain in the bladder), Aruchi (Anorexia), Mutrakriccha (Difficulty in micturition), Bastishira Vedana (Pain in Urethra), Mushka Vedana (Pain in testicles) and Shepha Vedana (Pain in the penis) have been described in Ayurvedic classical texts. A 29-year-old female patient visited OPD, with complaints of pain in the right side of the Abdomen, Burning Micturition, Nausea and Vomiting. The USG reported calculus measuring $5.3 \mathrm{~mm}$ in size seen in the right kidney with the normal functioning of vitals. The patient was treated with Chandraprabha Vati 2 BD, Gokshuradi Guggulu 2 BD, Varunadi Kwath 20ml BD on OPD basis. The patient was advised initially follow up after 7 days and later after every 15 days. Along with medication, the patient was also advised to follow diet and lifestyle restrictions. The patient got relief in signs and symptoms and the USG report showed no evidence of calculi in the right kidney. 
Keywords: Vrikashmari, Chandraprabha Vati, Gokshuradi guggulu, Varunadi Kwath

\section{INTRODUCTION}

Renal calculi are a common problem due to changing lifestyles. It is recurrent in nature. The cases of renal calculi are mostly Seen at age of 20-40 years and decline with over 50 years. Modern science stresses various factors like genetics, age, sex, metabolic disorders, Sedentary lifestyle, dehydration, the mineral content of water, nutritional deficiency etc. for Urinary stone formation. Urolithiasis causes pain, loss of working time, medical expenses, need for hospitalization and an infrequent reason for renal failure. In modern science, the best possible management for urinary calculus is the use of drugs to correct the involved Pathologies and use of diuretics as well as surgical intervention including open surgery, percutaneous techniques etc. ${ }^{[1]}$ The type of renal stones is Calcium oxalate, Uric acid and Cystines. Most calcium oxalate stones occur in $80 \%$ of the population. Other cases found of $20 \%$ renal stone type. Renal stone is resembling Ashmari in Ayurveda. Ashmari is the Disease that is coming under the Asthamahagad i: e difficult to cure. Ashmari is vyadhi which is considered under Mutravaha Strotas. As Basti come under Trimarma (threefold of Life) so Acharya Sushruta described Ashmari as darun (fatal) disease. Acharya Sushruta has been described as various medicines as well as surgical intervention for Vrikkashmari. Medicinal treatment is advised to be undertaken in the early stages of the disease. Indication of surgical management has been suggested along with a note of caution for complications. ${ }^{[2]}$ Surgical treatment must be accepted only on failure of conservative treatment and when death becomes inevitable.

In Ayurveda, there are various formulations like the use of various Ghrita Kwatha, Churna, Kshara Dravyas etc. ${ }^{[3]}$ Among those, Kwatha is used because they mostly have Mutrala and Bhedana properties.
In Ayurveda, 4 types of Ashmari are described by acharyas. Vatajasmari, Pittaj Ashmari, Kaphaj Ashmari and shukraj Ashmari. structure and symptoms are different. Vataj Ashmari symptoms resemble with Calcium Oxalate type Stone, Pittaj Ashmari symptoms resemble with Uric Acid type stone, Kaphaj Ashmari symptoms resemble with Oxalate/Phosphate type stone. Mostly Kaphaj pradhyanya dosh is involved in Ashmari.

1) Vataj Ashmari (Calcium Oxalate Stone) Vataj Ashmari is blackish, hard, irregular, rough structure and like Kadamb flower full of the spike on it. Symptoms are intense pain in the abdomen, Guda (Anal) region. Burning at penis, difficult to excrete Vata, Mutra, and stool.

2) Pittaj Ashmari (Uric Acid Stone) Pittaj Ashmari looks like bhallatak Asthi. Symptoms are burning Micturition, yellow urine.

3) Kaphaj Ashmari (Oxalate/ Phosphate stone) It is white, slimy, big in size, look like mahua colour. Symptoms are a pain in basti region, shaitya.

\section{Nidana of Vrikkashmari}

According to Acharya Sushruta-There are two main Nidanas of Vrikkashmari.

- Asamshodhana

- Apathyasevana.

\section{Samprapti of Ashmari}

According to Sushruta due to Apathya sevana and other etiological factors (Viruddha Vihara), having the vitiation of Kaphadosha of mutra leads to the formation of am and results in mandagni, kapha gets accumulated in vrikka and action of Ushma of Pitta, Shoshana by Vata Dosh leads to dries up the Mutra, the vitiated Kapha Dosha in the Vrikka Bhaga harden components lodged in. Mutra Ashmari is formed in the form of gravel and has become the obstruction in Mutravaha Srotas. 


\section{Apathya Sevan and other etiological factors (Viruddha Vihara)

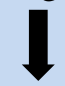

Ama Utpatti due to Jathragnimandhya

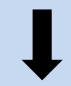

Aggravates Kaphadosha vitiation

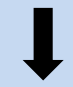

Vitiated Kaphadosha mixes with Mutra, Ushma and aggravated Vata dries up

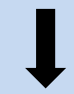

Mutra Sthanasnshraya at Vrikka

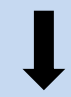

Ashmari (stone formed) in Vrikka

\section{Samprapti Ghataka-}

Dosha-Vata

Dushya-Mutra

Type of srotodushti- Sanga

Adhishthana-Basti

Strotas- Mutravaha

Agni- Jathragnimandhya

Marga-Abhyantara

\section{CASE STUDY}

A 29 -years old Female Patient came in OPD with symptoms of

- Pain in the right side of Abdomen

- Burning Micturition

- Nausea

- Vomiting

History of Present Illness -The patient was alright 3 months back, afterwards she is complaining of spasmodic pain on the right side of the Abdomen, Burning Micturition, Nausea, and vomiting. She had taken Opinion of Modern Diagnosed as Kidney stone. She took analgesics, antiemetic medicine but had Symptomatic Relief for some days. So, she comes here for further treatment.
Past History- She had no history of Diabetes Mellitus, Hypertension, Asthma, and Hypothyroidism or any type of Surgery.

Family History- Father -HTN, Mother-NAD

Clinical Examination-

Ashtavidh Prakisha

- Nadi-Vata pitta

- Mala-Samyaka

- Mutra- Daha

- Jivha-Sam

- Shabda-Prakrut

- Sparsha- Ushna

- Druka- Prakrut

- Aakruti-Madhyam

Per Abdomen Examination elicited tenderness on the right lumbar region of the Abdomen. No other Abnormality Detected during the general and systemic examination.

Vital Parameters- Vital Parameters were normal USG Report Shows- (06/01/2021)

The right kidney is normal in size $(10.9 \times 4.8 \mathrm{~cm})$ and outline. Shows an echogenic focus measuring approx. $5.3 \mathrm{~mm}$ with posterior acoustic shadow at upper pole calyx. cortical thickness and echogenicity are normal. 
Table 1: Therapeutic Intervention

\begin{tabular}{|l|l|l|l|l|}
\hline Sr No. & Name of Drug & Dose of Drug & Kala & Frequency and Anupana \\
\hline $\mathbf{1}$ & Chandraprabha Vati & 2 tabs & After food & Twice a Day with Lukewarm Water \\
\hline $\mathbf{2}$ & Gokshuradi Guggulu & 2 tabs & After food & Twice a Day with Lukewarm Water \\
\hline $\mathbf{3}$ & Varunadi Kwath & $20 \mathrm{ml}$ & Before food & Twice a Day with Lukewarm Water \\
\hline
\end{tabular}

Along with medication, diet and lifestyle restrictions were also advised to the patient. The patient was advised to drink plenty of water and avoid a proteinrich diet like egg, meat soybean, Dairy products etc, and Oxalate rich food like Spinach, Tomatoes, Ladyfinger, Chocolates, cold drinks etc and avoid Calcium supplements.

Table 2: Composition of Prescribed Formulation

\begin{tabular}{|l|l|}
\hline Medicines & Ingredients \\
\hline Vati & $\begin{array}{l}\text { Chandraprabha (Cinnamomum camphora), Vacha(Acorus calamus) Musta, (Cyperus rotundus) } \\
\text { Bhunimba, (Andrographis paniculata) Daruka, (Cedrus deodara) Haridra,(Curcuma longa) Ativi- } \\
\text { sha,(Aconitum heterophyllum) Darvi,(Berberis aristata) Pippalimoola, (Piper longum) Chitraka, (Plum- } \\
\text { bago Zeylanica) Trivrit, (Operculina turpethum) Danti, (Baliospermum montanum) Patra, (Cin- } \\
\text { namomum tamala) Twak,(Cinnamomum zeylanicum) Ela,(Elettaria cardamomum) Vamshalochana, } \\
\text { (bambusa bambos) Dhanyaka,(Coriandrum sativum) Haritaki, (Terminalia Chebula) Vibhitaki, (Termi- } \\
\text { nalia bellirica) Amalaki, (Emblica officinalis) Chavya, (Piper chaba) Vidanga, (Embelia ribes) Gajapip- } \\
\text { pali, (Piper chaba) Swarna makshika bhasma, Shunti, (Zingiber officinalis) Marich, (Piper nigrum) Pip- } \\
\text { pali, (Piper longum) Yava kshara, Swarjik kshara, Saindhava lavana, (Rock salt) Sauvarchala lavana, } \\
\text { Vida lavana, Loha Bhasma, Sita, (Sugar) Shilajatu (Asphaltum) Guggulu, (Commiphora mukul) }\end{array}$ \\
\hline $\begin{array}{l}\text { Gokshuradi } \\
\text { Guggulu }\end{array}$ & $\begin{array}{l}\text { Gokshur, (Terribulus Terrestris) Guggulu, (Comiphora mukul) Shunthi, (Zingiber officinale) Maricha, } \\
\text { (Pipper nigrum) Pippali, (Pipper longum) Haritaki, (Terminalia Chebula) Vibhitaki (Terminalia bellirica) }\end{array}$ \\
\hline $\begin{array}{l}\text { Varunadi Kwa- } \\
\text { tha }\end{array}$ & $\begin{array}{l}\text { Varuna (Crataevanurvala) Pashanbheda, (Berginialigulata)Shunti, (Zingiber Officinale) Gokshur } \\
\text { (Teribulus Terrestris) }\end{array}$ \\
\hline
\end{tabular}

\section{FOLLOW UP \& OUTCOME: -}

The patient was advised to follow up initially after 7 days and later after every $15^{\text {th }}$ day. Nausea and vomiting were Relieved and Mild relief in Burning Micturition within 7 days. However, mild intensity pain in the right side of the abdomen was there on the second follow-up visit, burning micturition was completely relieved. The pain was completely gone on the third follow-up and no other complaints were told by the patient. The patient was advised to repeat Ultrasonography (whole abdomen) scan after the fourth follow- up visit. A repeat Ultrasonography scan was done on the $19^{\text {th }}$ of March 2021 and did not reveal any renal calculus. Her urine examination reports were within normal limits. Clinically also. She has complete relief in pain abdomen, burning micturition, nausea, and vomiting. The patient was advised to carefully continue following diet and lifestyle restrictions to prevent the re-occurrence of calculus. No adverse events occurred during treatment and even after stopping the treatment. Details of follow-up have been given in Table 4. 
Table3: Ultrasonography and Urine examination Report

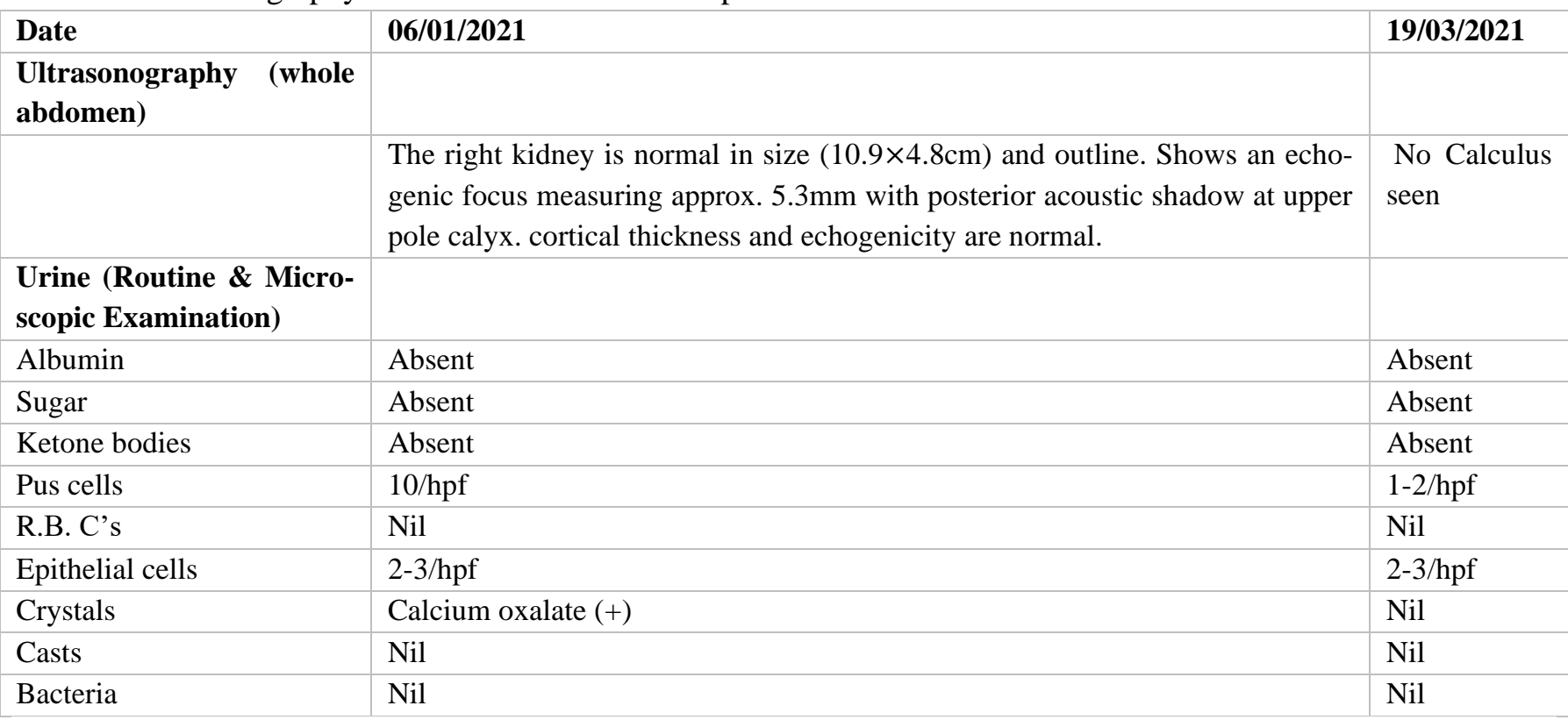

Table 4: TIMELINE

\begin{tabular}{|l|l|}
\hline Date & Details \\
\hline $06 / 01 / 2021$ & $\begin{array}{l}\text { The right kidney Shows an echogenic focus measuring approx. 5.3mm with posterior acoustic shadow at upper } \\
\text { pole calyx (Right Renal Calculus) }\end{array}$ \\
\hline $10 / 01 / 2021$ & $\begin{array}{l}\text { First visit to OPD Prescribed Ayurvedic Medicines Chandraprabha Vati, Gokshuradi Guggulu and Varunadi } \\
\text { Kwath along with Diet and Lifestyle Modifications }\end{array}$ \\
\hline $18 / 01 / 2021$ & $\begin{array}{l}1^{\text {st }} \text { Follow- up visit } \\
\text { Nausea and vomiting were Relieved, Mild relief in Burning Micturition, Right side Abdomen Pain was not } \\
\text { relieved. } \\
\text { Continue with the same medication. }\end{array}$ \\
\hline $02 / 02 / 2021$ & $\begin{array}{l}2^{\text {nd }} \text { Follow-up visit } \\
\text { Right side Abdomen Pain got mild in intensity, burning micturition was completely relieved. } \\
\text { Continue with the same medication. }\end{array}$ \\
\hline $17 / 02 / 2021$ & $\begin{array}{l}3^{\text {rd }} \text { Follow-up visit } \\
\text { Pain in the right side of the abdomen is completely gone with no other symptoms. } \\
\text { Continue with the same medication. }\end{array}$ \\
\hline $04 / 03 / 2021$ & $\begin{array}{l}4^{\text {th }} \text { Follow -up visit } \\
\text { No fresh complaints } \\
\text { Advised to do repeat Ultrasonography Scan } \\
\text { Continue with medications }\end{array}$ \\
\hline $19 / 03 / 2021$ & $\begin{array}{l}5^{\text {th }} \text { Follow-up Visit } \\
\text { No fresh Complaints } \\
\text { Ultrasonography Scan Revealed no Renal Calculus } \\
\text { Advised to continue Diet and Lifestyle restrictions to avoid reoccurrence }\end{array}$ \\
\hline
\end{tabular}

\section{DISCUSSION}

Acharya Susruta considered Ashmari as a grave disease and fatal as death itself. ${ }^{[4]}$ As per Ayurveda, the main reason for Ashmari is an aggregation of Kapha pradhana dosha in Mutravahasrotas due to $A g$ nimandya and Ama formation. ${ }^{[5]}$ The process of Ash- 
mari formation takes place by the stagnation and supersaturation of the urine and by crystallization of the crystalloids within the urine. ${ }^{[6]}$ The mechanism of renal calculus formation as per modern medical science is a complex process that ends up from various complex processes including supersaturation, nucleation, growth aggregation, and retention of urinary stone constituents within tubular cells. ${ }^{[7]}$ Despite a big selection of conventional medical intervention options, $50 \%$ of patients suffer a minimum of one recurrence, and $10-20 \%$ experience three or more further episodes of recurrence. ${ }^{[8][9] .}$ If left untreated or poorly treated, it could result in urinary tract infection, urinary obstruction, chronic kidney diseases, nephropathy, and hypertension. ${ }^{[10] ~[11] ~[12] ~}$

Ayurvedic drug management to disintegrate the pathogenesis of Ashmari includes the drugs with the following properties:

\section{Ashmari-Bhedana: -}

Disintegration, dissolution, expulsion, and to some extent prevention of urolithiasis like Gokshura (Tribulusterrestris Linn.), Varuna (Crataevamurvala Buch-Ham.). Pashanbheda (Bergeniaciliata Sternb.). Kulatha (DolichosbiflorusLinn.). Punarnava (Boerhaviadiffusa Linn.) etc [13-19]

\section{Mutrala: -}

Drugs that increase the urine production and are thus helpful in the expulsion of the calculas like Gokshura, Punarnava, Shvetaparpati, Trinapanchamula etc. ${ }^{[20-23]}$

\section{Deepana-Pachana: -}

Drugs to correct abnormalities in the digestion and metabolism (as the intermediary metabolites ( $a m a$ ) being excreted through the urinary tract could precipitate and give rise to urolithiasis) like Trikatu [Combination of Shunthi (Zingiberofficinale), Pippali (Piper longum). Maricha (Piper nigrum)]. Triphala [Combination of Haritaki (Terminaliachebula). Vibhitak (Terminaliabellerica). Amalaki (Phyllanthusemblica)]. Musta (Cyperusrotundus) etc.

\section{Vedanasthapana \& Shothahara}

Anti-inflammatory and analgesic drugs like Chandraprabha, Guggulu, Gokshura, Punarnava etc. ${ }^{[24-26]}$
The constituents of the prescribed medicines, Chandraprabha Vati Gokshuradi guggulu and Varunadi Kashaya have Ashmari Bhedana(lithotripsic). Mutrala (diuretic). vedanasthapana (analgesic). Shothahara (anti-inflammatory). basti-shodhana (improve kidney functions), Daha shamaka and deepanapachana (correct digestion and metabolism) properties as mentioned above. By means of these medicinal properties, the administered drugs have effectively disintegrated the pathogenesis of Ashmari and lead to expulsion of the Ashmari from the urinary tract in the present case.

\section{CONCLUSION}

Chandraprabha Vati, Gokshuradi Guggulu and Varunadi Kwath effectively disintegrated the pathogenesis of Ashmari, providing complete relief in burning micturition, dysuria, and expulsion of Ashmari from the urinary tract in the present case. This case shows the effective conservative management of Ashmari with Ayurvedic medicines with no adverse events.

\section{REFERENCES}

1. Role of imaging techniques in the diagnosis of Vrikkashmari (urolithiasis) and Shikhadi compound its management - Sharma Anilkumar-2001

2. Sushruta Samhita - Nibandha Sangraha, commentary by Dalhana.

3. Sushruta Samhita-Ayurveda Tattava-Sandipika Hindi commentary by Kavi Raj Ambika Dutt Shastri.

4. Patil VC. Rajeshwar NM editors Sushrut samhita of Susruta Chikitsasthana Ashmari chikitsa adhyaya: Chapter 07 Verse 03. First ed New Delhi Chaukhamba Publications 2018;348

5. Patil VC. Rajeshwar NM editors Sushrut samhita of Susruta Nidanasthana Ashmarichikitsadhyaya: Chapter 03 Verse 03. First ed New Delhi Chaukhamba Publications 2018; 26

6. Patil VC. Rajeshwar NM editors Sushrut Samhita of Susruta Nidanasthana Ashmarichikitsadhyaya: Chapter 03 Verse 25-26. First ed New Delhi Chaukhamba Publications 2018; 30

7. Alelign T. Petros B. Kinney Stone Disease: An Update on Current concepts. Adv. Urol 2018 Feb 4; 2018:3068365 
8. Hesse A. Brandle E. Wilbert D. Kohrmann KU, Alken P. Study on the prevalence and incidence of urolithiasis in Germany comparing the years 1979 vs 2000. EurUrol 2003: 44:709-713.

9. Strohmaier WL. Course of calcium stone disease without treatment. What can we expect? EurUrol 2000; 37: 339

10. Sigurjonsdottir VK. Runolfsdottir HL. Indridason OS, Palsson R. Edvardsson VO. Impact of nephrolithiasis on kidney function. BMC Nephrol. 2015 Aug 28: 16(1):149.

11. El-Zoghby ZM, Lieske JC. Foley RN, Bergstralh EJ, Li X, Melton LJ et al. Urolithiasis and the risk of ESRD.Clin J Am SocNephrol. 2012 Sep: 7(9):140915.

12. Taylor EN, Stampfer MJ. Curhan GC. Obesity, weight gain, and the risk of kidney stones. JAMA 2005 Jan 26; 293 (4):455-62

13. Pramod K. Despande PS. Singh CM. Studies on urolithiatic action of Indigenous drugs. Bull. Med. Ethnobot 1981: 2: 277-84

14 Varalakshmi P. Shamila Y. Latha E. Effect of Crataevanuruala in experimental urolithiasis. J. Ethnopharmacol. 1990, 28: 313-21

15 Agarwal S. Gupta SJ. Saxena AK. Gupta N. Agarwal S. Urolithic property of Varuna (Crataevanurvala); An experimental study. AYU 2010 Jul-Sep. 31 (3): 36166

16 Havagiray RC. Shashi A. Jain SK, Sabharwal M. Herbal treatment for urinary stones. International Journal of

17 Pharmaceutical Sciences and Research 2010: 1: 24-31 20. Sangeeta D. Sidhu H. Thind SK. Nath R. Effect of Tribulusterrestris on oxalate metabolism in rats. J Ethnopharmacol 1994 Oct 44(2):61-66.

18 Yas F. Waqar MA. Effect of indigenous plant extracts on calcium oxalate crystallization having a role in urolithiasis. Urol Res. 2011 Oct, 39(5):345-50.

19 Balap LG Evaluation of Anturolithiatic Activity of the Aqueous and Alcoholic Extracts of Roots of BoerhaaviaDiffusa LAJPR 2015, 5(1): 525-30.

20 Chhatre S. Nesari T. Somani G. Kenjale R. Sathaye S. Comparative Evaluation of Diuretic Activity of Different Extracts of Tribulusterrestris Fruits in Experimental Animals. Int $\mathbf{J}$ Res PhytochemPharmacol. 2012; 3:129-33.

21 Singh RP. Shukla KP. Pandey BL, Singh RG, Usha, Singh RH. Recent approach in clinical and experimental evaluation of diuretic action of Punarnava (B. diffusa) with special reference to nephrotic syndrome. J. Res Educ. Indian Med. 1992. 11. 29-36.

22 Balakrishnan G. Vineeth PK. Ramesh NV. Effect of ShwethaParpati in Mutrakrichra: An Article Review. Joumal of Medical Pharmaceutical and Allied Sciences 2017; 1(1): 588-95.

23 Chunekar KC. editor BhavaprakashaNighantu of Bhavprakasha, Reprint ed. Varanasi: Chaukhambha Visvabharati 2006; p32

24 Baburao B. Rajalakshmi G. Venkatesham A. Kiran G. Shyamsunder A. Gangarao B. Anti-inflammatory and antimicrobial activities of methanolic extract of Tribulusterrestris Linn. Plant. Int J Chem Sci. 2009: 7: 1867-72.

25 Asadulla S. Anti-inflammatory activities of Boerhaviadiffusa roots in Albino rats. Archive of Pharmaceutical Science \& Research 2010, 2:267-70.

26 Francis JA. Raja SN, Nair MG. Bioactive terpenoids and guggulu steroids from Commiphora mukul gum resin of potential anti-inflammatory interest. Chembiodivers 2004 Nov;1(11):1842-53.

\section{Source of Support: Nil Conflict of Interest: None Declared}

How to cite this URL: Neha Grover et al: $\mathcal{A}$ Case Study On Ayurvedic Management of Vrikkashmari. International Ayurvedic Medical Journal \{online\} 2021 \{cited October 2021\} Available from: http://www.iamj.in/posts/images/upload/2598_2604.pdf 